\title{
HasanuddinLawReview
}

\section{Tendering in Assignment of the Administrative Contract: A Comparison of Egyptian Tender Law and Saudi Government Tenders and Procurement Law}

\author{
Awad Ali Alanzi \\ Department of Law, College of Business Administration, Prince Sattam Bin Abdulaziz University, Saudi \\ Arabia. E-mail: dr.awad.alanzi@gmail.com
}

\begin{abstract}
Administrative contracts are conducted to meet government agencies' requirements in terms of procurement, which is done by tendering. The government infrastructure demand and day-to-day other needs are contracted with vendors, who render their services by applying the announced tender. Hence, the legal framework related to tendering is very important, which protects the legal rights of tender authority and vendors. This present research aims to explore the tendering law in Saudi Arabia and Egypt, having a close legal framework regarding tendering. Egypt is carrying the tender law of 1998, which is updated in 2018 recently. Moreover, tendering in Saudi Arabia depends on the Government Tenders and Procurement Law (GTPL) of 2019, which is updated from the previous version of GTPL 2006. The research explores the basic structure of the procurement system and tendering in both systems, including the discussions on procurement agency, tendering methods, basic tendering regulations, public-private partnership, transparency issue, and tendering with foreigners' bidders. Also, the recent improvements in both tendering systems are discussed. The research traces many similarities and differences in both tendering systems and suggests taking help from each other's experiences.
\end{abstract}

Keywords: Administrative Contract; Tendering; Tender Law; Public-Private Partnership; Vendors

\section{Introduction}

The government contract develops the relationship between government authorities with another government body or the ordinary non-government entity. Hence, publicprivate partnerships are expected due to some common interests. ${ }^{1}$ This contract binds the two parties to perform their mutually agreed tasks and care for the rights and obligations of each and another, in which one party is a government body. Moreover, the legal framework protects the rights of both contracting parties with the help of a judicial

\footnotetext{
${ }^{1}$ Buchanan, J.M., \& Tullock, G. (1999). The calculus of consent: the logical foundation of constitutional democracy. Available from: <http://www.econlib.org/library/Buchanan/buchCv3c3.html>. [Accessed: 21 October 2020]
} 
dispute tenacity approach. ${ }^{2}$ Particularly, administrative contracts' legal prudence would help the country's mass-reconstruction, which needs private-public partnership to complete the government-planned projects. Legal powers reflect the capacity of courts in this regard to resolve commercial disputes. Moreover, the judicial system should be free from political pressure to float decisions based on the legal framework. ${ }^{3}$

Administrative contracts might be benefitted from the common contract law, but many unique features of public contracts traced the importance of separate procurement law in any country. ${ }^{4}$ Moreover, government bodies carry extraordinary features over ordinary contracts because of the disparity of power in the bargaining, enormous spending plans, and caring public interest. ${ }^{5}$ Government bodies might perform weakly in contracting and would result in lower quality of government services. ${ }^{6}$ On the other hand, the procurement system depends on a large number of bidders in the tendering process. ${ }^{7}$ Hence, it may promote competition and efficiency in the tendering and procurement systems by receiving different price options and selecting the lowest bid price.

Saudi Arabian government has a great plan of projects and construction as per the Kingdom's Vision 2030. The administrative contract's legal framework would play an influential role in devising the government and contractors' rights and duties. Under the umbrella of this legal framework, the courts may resolve the disputes after assessing the parameters defined in the law. ${ }^{8}$ Hence, the law protected the proper regulation of the activities and improved accountability. ${ }^{9,10}$ Moreover, the regulations played their arbitrating role among the private sector and the government agencies in case of disputes. Judicial review is essential to understand the areas of improvement in the legal framework to facilitate economic and social activities for its maximum economic and social welfare. ${ }^{11}$

Legal reform always plays a significant role in understanding the present needs of a country and society. It also helps to upgrade the legal system to meet the current requirement of society's needs. Saudi Arabia and Egypt have upgraded the procurement

\footnotetext{
2 Posner, E. (2008). Does political bias in the judiciary matter?: Implications of judicial bias studies for legal and constitutional reform. The University of Chicago Law Review, 75(2): 853-883. doi: http://dx.doi.org/10.2139/ssrn.1082055

3 Gillespie, J. (2007). Rethinking the role of judicial independence in socialist-transforming East Asia. The International and Comparative Law Quarterly, 56(4): 837-869. doi: https://doi.org/10.1093/iclq/lei203

${ }^{4}$ Massengale, E.W. (1991). Fundamentals of Federal Contract Law. Praeger Publishers, Westport, United States.

${ }^{5} \mathrm{Nagle}$, J.F. (2000). How to review a federal contract and research federal contract law. American Bar Association, Chicago, United States.

${ }^{6}$ Marvel, M.K., \& Marvel, H.P. (2007). Outsourcing oversight: a comparison of monitoring for in-house and contracted services. Public Administration Review, 67(3): 521-530. doi: https://doi.org/10.1111/j.15406210.2007.00734.x

${ }^{7}$ Alofi, A., Alhammadi, Y., Kashiwagi, D., Kashiwagi, J., \& Sullivan, K. (2015). Upgrade the Saudi Arabian Procurement System Delivery Method. Journal for the Advancement of Performance Information and Value, 7(1): 146. doi: https://doi.org/10.37265/japiv.v7i1.60

8 Lehmkuhl, D. (2008). On government, governance and judicial review: The case of European Competition Policy. Journal of Public Policy, 28(1): 139-159. doi: https://doi.org/10.1017/S0143814X08000810

9 Bell, J. (2013). Path dependence and legal development. Tulane Law Review, 87: 787-810. doi: https://doi.org/10.17863/CAM.38906

10 Botero, J. C., La Porta, R., López-de-Silanes, F., Shleifer, A., \& Volokh, A. (2003). Judicial reform. The World Bank Research Observer, 18(1): 61-88. doi: https://doi.org/10.1093/wbro/lkg005

11 Supra, Posner.
} 
system in 2019 and 2018, respectively, to meet the current age requirement and challenges. The present study tries to explore the basic procurement system regrading to the administrative contract and application of tender in the legal systems of Saudi Arabia and Egypt. It also aims to explore the recent amendments in both systems to understand these countries' legal reforms in the domain of public procurements. These two countries are chosen because both share many common features in the legal framework regarding procurement and have done recent reforms. The literature has signified the importance of judiciary review. ${ }^{12,13,14,15}$ Hence, there is a need to understand the current Saudi Arabian and Egyptian procurement systems' recent reforms, which is absent in the literature. The present study tries to fill this literature gap.

\section{Procurement Agencies and Basic Structure of Procurement System and Tendering}

Before the amendment of 2008, 2010, and 2018, the tender law of 1998 explained the legal regulations regarding the government procurement in Egypt as per the Ministry of Finance notification. ${ }^{16}$ Moreover, it is complemented by legal scholars and the Civil Law Articles 668-673, where tender law 1998 could not deliver some civil and sharia matters. ${ }^{17}$ In addition, this law explains the details to support the tendering process from application to the project completion stage. The last phase of tendering is relatively weakly defined in the law compare to the initial and intermediate processes. However, the law advocates the principles of transparency, competition, and quality. ${ }^{18}$ The government agencies should publicly announce the tender with complete information about requirements to ensure all bidders' equal participation and ensure a wise competition. However, the local companies may have a price advantage of 15 percent compared to the foreign firms to promote local firms' participation in public procurement. ${ }^{19}$ Hence, the law discriminates against and discourages foreign firms from the local public procurements, and many developing countries are adopting such

\footnotetext{
12 Emmert, C.F. (1992). An integrated case-related model of judicial decision making: Explaining state Supreme Court decisions in judicial review cases. The Journal of Politics, 54(2), 543-552. doi: https://doi.org/10.2307/2132038

${ }^{13}$ Crowley, D. W. (1987). Judicial review of administrative agencies: Does the type of agency matter? The Western Political Quarterly, 40(2): 265-283. doi: https://doi.org/10.1177/106591298704000205

14 Kapiszewski, D. (2011). Tactical balancing: High court decision making on politically crucial cases. Law and Society Review, 45(2): 471-506. doi: https://doi.org/10.1111/j.1540-5893.2011.00437.x

15 Sunkin, M. (1987). What is happening to applications for judicial review?, the Modern Law Review, 50(4): 432467. doi: https://doi.org/10.1111/j.1468-2230.1987.tb01720.x

16 EBRD European Bank for Reconstruction and Development (2013). Public Procurement Sector Assessment: Review of Laws and Practice in the SEMED region - Egypt, Jordan, Morocco, Tunisia. Available from: < http://www.marchespublics.gov.tn/onmp/upload/documents/ebrd_report_eng.pdf>. [Accessed: 08 October 2020]

17 World Bank (2003), Arab Republic of Egypt Country Procurement Assessment Report, December 2003 Operational Core Services Middle East and North Africa Region. Available from: <http://siteresources.worldbank.org/INTMNAREGTOPGOVERNANCE/Resources/CPAREGYPT2003.pdf>. [Accessed: 17 October 2020]

18 Institute for Public-Private Partnerships (IPPP) (2003). Review and analysis of the Egyptian Tender Law and its Executive regulations. Governorate of Alexandria, Governorate of Cairo, Governorate of Qalyoubiya, Egyptian Environmental Policy Program, and the United States Agency for International Development. Available from: <https://www.scribd.com/document/216672276/Review-and-Analysis-of-the-Egyptian-Tender-Law-and-ItsExecutive-Regulations>. [Accessed: 12 July 2020]

19 Ibid, Article 16
} 
practices to promote their local companies. ${ }^{20}$ Moreover, the preference was also given to locally produced goods for public procurement to promote the local manufacturing of either private or government-owned enterprises. ${ }^{21}$ However, some government bodies are exempted from these conditions to protect their interest and needs, particularly in the case of national security issues. Moreover, small and medium producers may also be preferred with a wide range of relaxations. This law carries the regulation regarding the procurement of goods, constructions, and leasing and rental land matters. ${ }^{22}$

The procurement system in Saudi Arabia is worked on the newly reformed GTPL in 2019, which is updated from the previous version of GTPL 2006. The new GTPL improves the competition in the procurement system along with enhancing transparency and justice. It has improved the rights of both contracting parties in the whole process of tendering administrative contracts. It legitimizes the utilization of services of the arbitrators in case of disputes. The Unified Procurement Agency (UPA) is introduced in the system to audit the problems during the bidding of public tenders. Additionally, to support the governmental agencies in identifying the works, procurements needed, unifying the technical specifications, reviewing feasibility studies and cost estimates, developing forms for tender documents, pre-qualification documents, contracts, and contractor performance assessment. GTPL provides the services of E-Portal for bidding and reversebidding. It also helps to choose the lowest price offer with transparency and ensures the vendor's tendering ability. ${ }^{23}$

In Saudi Arabia, the Ministry of Finance (MOF) is responsible for tendering the procurement system. For this purpose, the MOF may also be appointed the UPA to ensure the equality of the contractors' rights in tendering process and to protect the cohesive deliberated procurement system as per the fundamental essence of procurement legislation and regulations. The Egyptian procurement system is governed and regulated by the Egyptian MOF. MOF is a responsible agency to deal with the execution and implication of regulatory matters regarding public procurements. All other government agencies should follow the rules and regulations defined by MOF in the case of public procurement and tendering. The public body announces the need for procurement, which is called the administrative agency. The concerned ministry of procurement is called an authority. ${ }^{24}$ Moreover, General Authority for Governmental Services (GAGS) is working as an agent to MOF, participates in the evaluation committee to watch the budgetary matters, and can monitor all financial matters related to the procurement. Hence, this agency ensures a centralized type of procurement and government purchases. Moreover, GAGS writes an audit report to ensure transparency

${ }^{20}$ EBRD European Bank for Reconstruction and Development (2013). Public Procurement Sector Assessment: Review of Laws and Practice in the SEMED region - Egypt, Jordan, Morocco, Tunisia. Available from: < http://www.marchespublics.gov.tn/onmp/upload/documents/ebrd_report_eng.pdf>. [Accessed: 08 October 2020]

${ }^{21}$ Ministry of Foreign Trade (2002). Developing a Procurement Reform Program Supporting SME Development in Egypt: A Background Study. Available from: <http://www.mof.gov.eg/MOFGallerySource/English/SME/ Research_studies/4.pdf>. [Accessed: 13 January 2016]

22 Supra. IPPP, Articles 2-42

23 Government Tenders and Procurement Law (GTPL) (2019). Government Tenders and Procurement Law, Articles 1-87. Financial Knowledge Center, Ministry of Finance. Available from: < https://www.mof.gov.sa/en/ Documents/Government_Tenders_and_Procurement_Law.pdf >. [Accessed: 15 June 2020]

24 Supra. IPPP, Article 2 
in all procurement procedures, and it reports if found any deficiency in procurement regulation compliance. ${ }^{25}$

\section{Tendering Methods and E-Bidding}

In the Egyptian system, the public tender mainly gears the procurement. It starts with an open competition of bidding. It is applied by offering the financial and technical proposals of the advertised procurement. Moreover, the financial proposal may be allowed to revise as per the direction of the procurement authority. In addition, some exceptions are also allowed for limited and local tendering and in case of direct purchase. A performance guarantee is required in direct contracting, but the tender bond is not required, which is done by a public sector contractor. The projects' announcement was made by newspapers for bidding for small and medium projects. Moreover, international publications were also a source of advertisement in large projects to disseminate the project opening information at the international level. After the revolution of information technology, the bidding system is shifted to electronic means. The government launches a website to display the specifications and requirements of projects and ask for bidding. Moreover, the publicity of the locally manufacturing goods is also allowed through this website to promote the local producers in the administrative contract. ${ }^{26}$

In Saudi Arabia, MOF provides a website to apply for public tenders. The financial and technical abilities of the vendors are judged on the specified parameters. The tendering should be performed in the Arabic language. The tender should be submitted with a 1-2 percent bid guarantee. The tendering proposal must go through the review process before approval decisions. Then, the review committee may float their recommendations as per the best bidder's offer and financial and non-financial abilities. Moreover, the UPA worked as an agency to ensure transparency in the bidding procedure of tendering. The review committee may also ask for the revision of price as per the market price if other qualifications are found superior over other bidders. Moreover, the second choice may be consulted if the best bidder fails to follow the reviewers' recommendations. On the other hand, the committee may also propose the tender authorities to reduce their requirements if the project's expected budget is exceeded the approved budget as per UPA's recommendations. ${ }^{27}$

The website of MOF (Etimad) facilitates the procurement and tendering procedure in the Kingdom. On this website, all rules and regulations of tendering are mentioned. The website conducts all announcements, application of tendering, and monitoring all the process from application to completion of public projects. Moreover, the website also contains a list of people who are not allowed for tendering because of punishment of any violation. In addition, the terms and conditions of approved tenders are also displayed on

\footnotetext{
25 Organization for Economic Cooperation and Development (OECD) (2016). Stocktaking Report on MENA Public Procurement System, MENA-OECD Network on Public Procurement, Paris: OECD. Available from: <https://www.oecd.org/governance/ethics/Stocktaking_MENA_Public_Procurement_Systems.pdf>. [Accessed: 02 December 2020]

${ }^{26}$ Supra. IPPP, Article 9

27 Supra. GTPL, Articles 1-47
} 
the website. ${ }^{28}$ However, any tender related to national security may be avoided to publish on the website. ${ }^{29}$ This website confirms the security and transparency of all tendering procedures, and all tender-related information are available for concerned vendors. Moreover, the website contains all types of data on different stages of tendering as per regulation. However, the MOF may ask for some charges to use the website for tendering purposes, and ministers of the council decide and recommend the ministry for this purpose. ${ }^{30}$ All required documents related to tendering are made available through the website. All types of public tendering are conducted through this portal. ${ }^{31}$ Tender bidding, its reversal, and information of winners might be found on the website. ${ }^{32}$ Moreover, the movable auction procedure is also conveyed through a portal. ${ }^{33}$

\section{Basic Tendering Regulations}

In Egyptian law, a bid must not be canceled after its opening. Changes in the tender are not allowed after its execution. The final decision on the bids should be written with a reason behind the decision. A bid bond of one percent of total value should be submitted with the contractors' applications, and a five percent performance bond of total value should be submitted by the winner of the bid. On the other hand, the contractors of locally produced goods have to submit fifteen percent of total value as a performance bond. ${ }^{34}$ After the expiration of the tender, the bid bond would be returned. A ministry would allow appointing a proper legal body for dispute settlement in case of disputes among parties of the administrative contract through negotiation, mediation, or consensus-building.

The appeal against any violation may be submitted to a particular office in MOF without going to court. However, a bidder has the right to go to court if he is not satisfied with the decision of MOF on his appeal. In addition, an arbitrator's role may also be utilized in case of disputes in the administrative contract after approval of the competent authority. In this context, a legal opinion was issued, which prohibited the arbitration in the administrative contract. ${ }^{35}$ Some ministries have developed their own rules regarding disputes settlements as discretionary powers, which becomes the source of settlements. However, it weakens the transparency principle of the administrative contract. A direct purchase is allowed in the case of security agencies like defense and military production ministries. Moreover, a condition of local manufacturing preferences is also relaxed in these security agencies.

In the Saudi system, tendering is performed through an ordinary and an electronic auction system, and a tender application must be submitted in the Arabic language. A 1$2 \%$ bid guarantee should be submitted to ensure a bidder's solid financial position.

\footnotetext{
28 Supra. GTPL, Articles 1,13,14

${ }^{29}$ Supra. GTPL Article 16

30 Supra. GTPL Article 17

31 Supra. GTPL Article 29

32 Supra. GTPL Article 37

33 Supra. GTPL Article 80

${ }^{34}$ Supra. IPPP, Article 16

35 Supra. EBRD, 2012, 2013
} 
However, the bid guarantee's relaxation may be given in exceptional circumstances or for a special contract type. The tender is announced publically with an apparent requirement of the project and guiding the methods of application. The vendors may then offer their bids, and the number of bidders should not be lesser than five in a limited tender. However, lesser bidders may participate in bidding in a low-value project (i.e., less than a hundred thousand project value). It is allowed for direct purchase in case of lesser availability of vendors in the country for a very specialized project. Afterward, a review committee is appointed consisted of many members from different ministries. With UPA interference, the proposal review committee is responsible for all selection procedures and to make them transparent and competitive. The award of a contract is given to the best bidder based on the bidder's financial and technical qualifications.

A proposal review committee follows the principle of fair prices to make decisions based on the best bid in terms of prices, technical and administrative capacity through an electronic system. The committee gives recommendations regarding the revision of the tender proposal to reduce the contract's cost. The committee may also suggest the tender authority, if needed, an adjustment in the work requirement per sanctioned budget. Equality and transparency are most critical in GTPL procedure as per new GTPL law in the Kingdom. So, all vendors are treated equally in terms of tender information and other wanted requirements. A tender may be canceled any time of awarding the project if any evidence of corruption is proved or a project looks against the public interest. The head of awarding authority has a direct look at the tendering procedure to ensure a competitive environment. However, a delegation may be worked with a chain of command if the project has a total value of lesser than ten million. Moreover, tendering authority may also perform direct purchases if the project value is less than three million.

The tendering authority provides the assessment forms and procedures to observe the ongoing performance of a project. In case of approval of a project, the $5 \%$ performance guarantee should be submitted within fifteen days of approval, and the work of contracts should be started within sixty days of award. A contract may be canceled if it could not initiate work within the prescribed time or in case of illegal activities or insolvency of the contractor. A contract should be completed by the awarded contractor, and subcontracting is allowed only with approval from the tendering authority. A right of complaint is also available with contractors to contact the court if they faced any breach of contractual obligations by the government agency or found any other activities that discouraged their rights. As per new GTPL law, the arbitration is allowed in disputes administrative in contracts whose estimated value is exceeds (one hundred million) SAR, where foreign law interferes with the process of contracts. ${ }^{36}$

\section{Public-Private Partnership and Transparency in Administrative Contracts}

In Egypt, the procurement law is appreciated the public-private partnership in the administrative contract to promote the private sector. For example, the law allows concessions to the private sector to use public utilities in a particular sector like the

\footnotetext{
${ }^{36}$ Supra. GTPL, Articles, 1-72
} 
railway sector. In addition, the procurement law may also have exemptions for publicprivate partnership projects. The law was also amended in 2010 in favor of public-private partnerships. ${ }^{37}$ These regulations were framed to attract foreign investment in the country. However, the implication of these special laws for public-private partnerships seems weak in the country, and foreign investment could not be attracted. ${ }^{38}$

The Egyptian law discourages corruption in the process of tendering and bidding. The GAGS might be involved to prove the corruption in the bidding process. In case of the commitment of corruption, the public sector employees are subjected to heavy penalties and fines. However, these penalties are relaxed in the case of the private sector. Moreover, the legislation could not bind the foreigners in case of the commitment of corruption. In addition, the authorities may ban the parties for a lifetime if they are found in the corruption activities. A court decision can only remove this ban. In the procurement procedure, the standard documents are missing to elaborate the rights and duties of contracting parties. ${ }^{39}$ Therefore, the public agencies are developing their own documents and discouraging the standardization in the bidding process.

In Saudi Arabia, Saudi authorities also prefer the local privately owned business for public tendering to promote the public-private partnership in GTPL. Notably, the public limited companies listed with Tadawal are preferred over the others to promote local private companies' role in the tendering process. Moreover, Saudi small and medium businesses are also preferred to promote small and medium enterprises in public-private partnerships. ${ }^{40}$ In addition, the bidding system reduces the cost of applying the tender to promote small business participation in tendering. In contrast to the Egyptian system, no concessions are provided to private businesses in public projects; which is given in local bids only.

Saudi GTPL is highly geared to control corruption and favoritism in all processes of tendering. In the case of any violation of tendering and contracting regulations, the tender would be canceled without the rights of appeal. Moreover, any fraudulent and corruption-related activities in all tendering processes may disqualify the vendor from tendering process, and the contract would also be canceled. ${ }^{41}$ To make tendering procedures clear out of malpractice, all procedures are carried on the portal, ensuring the doctrine of competition, equal treatment to vendors, and control of corruption. ${ }^{42} \mathrm{~A}$ blacklist is also published on the website to disqualify the corrupted vendors in the tendering procedure. ${ }^{43}$

\footnotetext{
37 Supra. EBRD, 2013

38 Organization for Economic Cooperation and Development (OECD) (2014). Business Climate Review of Egypt: Investment Policies and Public Private Partnerships, Paris: OECD. Available from: <http://www.oecd.org/mena/ competitiveness/BCR\%20Egypt_April29_with_cover.pdf>. [Accessed: 22 January 2021]

39 Supra. IPPP, Article, 8

40 Supra. GTPL, Article 9

41 Supra. GTPL, Article 51

42 Supra. GTPL, Article 17

43 Supra. GTPL, Article 13
} 


\section{Tendering with Foreign Bidders}

The international contract would be conducted between the government of one country and the foreign bidders for tendering purposes. ${ }^{44,45}$ Moreover, foreign agencies may also be hired to sell local products in the international market because of their international market experience. ${ }^{46}$ The foreigner bidders are allowed to participate in the bidding process to apply for a tender in the case of large projects in Egypt. For this purpose, bidding is announced at the foreign platforms using both Arabic and English languages. However, the local bidders are preferred in small and medium level projects and in the case of locally manufactured goods. The locally manufactured products might be preferred with a maximum fifteen percent higher price than those offered by foreign manufactured products. Local bidders' definition is that these contractors should have business activities in the governorate of the announced tender. The foreign companies may join as sub-contractors in the construction contract, and the local contractors must be appointed as principal contractors in these projects.

In the case of Saudi Arabia, a foreign bidder is allowed to offer bids in case of the nonexistence of a local vendor in the Kingdom. ${ }^{47}$ However, the Saudi government promotes the local vendors from the small, medium, and large listed companies over the foreign bidders. ${ }^{48}$ In the case of foreigners' bidding, the bidder must follow all local tendering regulations in the bidding process. The Saudi government allows the public bodies to form foreign contracts with foreigners if it favors public welfare. ${ }^{49}$ Some exemptions may also be awarded in foreign tendering. ${ }^{50}$ The government usually avoids foreign vendors due to the difference in tendering regulations in foreign countries. Local Saudi law may not work in case of any dispute in the foreign jurisdiction. Moreover, arbitration is also discouraged in public tendering as per regulations. Nevertheless, the new GTPL of 2019 allows the arbitration in case of dispute in a tendering with a total value of more than one million, which applicability falls outside the boundary of Saudi Arabia. The arbitration body may be consulted in this case, which is not permissible to accept arbitration with international arbitration bodies outside the Kingdom. However, international arbitration bodies may be accepted in contracts with foreign persons. The arbitration body may be consulted in this case, which must be a commercial body. The arbitration body should follow the local regulations. Because if the arbitrator ignores the local Saudi regulations, then it may harm the national sovereignty issues. ${ }^{51}$ In an argument, it also stated that

\footnotetext{
${ }^{44}$ Hofmann, V, Rowe, R.C., \& Turk, A. (2011). Administrative Law and Policy of the European Union. Oxford University Press, Oxford, United Kingdom.

${ }^{45}$ Salama, A.A. (1984). International contracts for investment and economic development. Cairo, Egypt.

46 Bakr, M.A. (2000). The administrative contract across the boundaries. Dar Al-Arab renaissance, Riyadh, Saudi Arabia.

47 Supra. GTPL, Article 3

48 Supra. GTPL, Article 9

${ }^{49}$ Al-Jarbou, A.M. (2011). Administrative Contract under Saudi Arabian law. Public Contract Law Journal, 41(1): $75-$ 88.

50 Supra. GTPL, Article 11

51 Supra. GTPL, Article 92
} 
arbitration moved the local jurisdiction to an international arbitrator, who may ignore the local law. ${ }^{52}$

\section{New Public Contract of 2018 in Egypt}

In 2018, the Egyptian parliament announced a new public contract law after MOF's recommendations to support the country's social and economic challenges. To reduce government spending, renting is preferred instead of purchasing movable items for public procurement. As per Article 4, a committee is designed to figure out the country's economic changes with the ministries' support associated with economic affairs. As per new economic challenges, this committee recommends suggestions to the administrative agencies to improve the service quality. This new law is mainly focused on reducing the government bodies' corruption to improve public bodies' performance and rationalize government spending at the lowest possible level. As per Article 7, the tendering process must be followed for any type of administrative contracts related to movable or immovable and related to the public services. However, the new law did not discourage the exceptions in case of direct purchase and local, limited, and 2-stage tendering. ${ }^{53}$

The new law enforces the bidding on closed-envelope for any contract regarding public movables except the local and limited bidding, with competent authorities' approval. Moreover, the contracts' splitting is banned to follow uniform rules and regulations written in Article 10. Moreover, Article 11 suggests the administrative bodies to ensure the availability of funds for the projects' needful requirements before starting tendering. The contracts and tendering are not allowed for the last month of a financial year, except the need-based cases approved by ministers. In the case of corruption and the nonexistence of competition, the tenders would be canceled in all types of contracts as per Article 37. Article 40 is stated the insurances' performance rate as per the nature of trades. In case of the contract's cancellation, the contract is not obliged to pay the final insurance. The administrative body needs a timely response to the contract as per agreed terms and conditions. The contractor may request an inquiry in case of failure as per Article 49. ${ }^{54}$ The private sector is allowed to participate in infrastructure-related projects or public utilities. The principle of equal opportunity is highly appreciated to ensure a competitive environment and control corruption. ${ }^{55}$

\section{New GTPL 2019 in Saudi Arabia}

The Saudi government has announced a new GTPL in the year 2019 to ease the procedure for foreign contractors and consultants to support its infrastructure programs. The GTPL of 2019 had some strict terms and conditions for the government tender and procurement system. The GTPL may be applied to all government bodies and entities as per latest versions of GTPL. However, the new GTPL allows a more centralized tender

\footnotetext{
52 Barraclough, A., \& Waincymer J. (2005). Mandatory Rules of Law in International Commercial Arbitration. Melbourne Journal of International Law, 6(2): 205-244. doi: https://doi.org/10.3316/INFORMIT.045588601691846

53 Supra. IPPP

54 Ibid

55 Saleh, Y. (2020). Egypt: The new Public Contracts Law No. 182 of 2018. Lexocology, London.
} 
approach. For example, the central public body may announce a tender for a central work in the case of multiple government agencies. The central electronic portal would be used for bidding or reverse auction purposes. The public bodies should follow the same process and forms of agreement, which are provided by the central public body. The public bodies are also complimentary for some variations in case of undetermined or uncertain types of work. The public tender may be ignored if consultant services are acquired based on a limited tender. The failed bidders are allowed to raise complaints within 5-10 days of the decision, and the announcement of an award should not be issued until completion of this time. The MOF's approval is required if the contract is allocated from the state's general budget. Otherwise, the ministry's approval is not needed in case of a separate special budget. A penalty for the delay is increased from a maximum of $10 \%$ to $20 \%$ in the new GTPL. The arbitration is allowed after the MOF's approval, and the Board of Grievances may be consulted otherwise. ${ }^{56}$

\section{Conclusion}

Tendering procedures and tender law are very important in understanding the basic administrative contract mechanisms for government procurements. This study explores Saudi Arabia and Egypt's tendering legal framework to compare the tendering process and procurement systems' basic similarities and differences. The Egyptian tender law depends on the basic version of 1998, and Saudi Arabia follows the basic rules of GTPL 2006. Moreover, this study explores the latest advancements in both procurement systems in 2018 and 2019 in Egypt and Saudi Arabia, respectively. The research explores the basic structure of the procurement system and tendering in both systems, including the discussions on procurement agency, tendering methods, basic tendering regulations, public-private partnership, transparency issue, and tendering with foreigners' bidders. The study finds many similarities in both systems, along with potential differences. Hence, it is suggested that both systems would be benefitted from each other's experiences in tendering and procurement procedures to improve their systems.

\section{References}

Al-Jarbou, A.M. (2011). Administrative Contract under Saudi Arabian law. Public Contract Law Journal, 41(1): 75-88.

Alofi, A., Alhammadi, Y., Kashiwagi, D., Kashiwagi, J., \& Sullivan, K. (2015). Upgrade the Saudi Arabian Procurement System Delivery Method. Journal for the Advancement of Performance Information and Value, 7(1): 146. doi: https://doi.org/10.37265/ japiv.v7i1.60

Bakr, M.A. (2000). The administrative contract across the boundaries. Dar Al-Arab renaissance, Riyadh, Saudi Arabia.

\footnotetext{
56 Kerur, S., \& Edwards, C. (2020). The New KSA Government Tenders and Procurement Law. Reed Smith driving through partnership, Dubai. Available from: <https://www.reedsmith.com/en/perspectives/2020/02/the-new-ksagovernment-tenders-and-procurement-law>. [Accessed: 20 August 2020]
} 
Barraclough, A., \& Waincymer J. (2005). Mandatory Rules of Law in International Commercial Arbitration. Melbourne Journal of International Law, 6(2): 205-244. doi: https://doi.org/10.3316/INFORMIT.045588601691846

Bell, J. (2013). Path dependence and legal development. Tulane Law Review, 87: 787-810. doi: https://doi.org/10.17863/CAM.38906

Botero, J. C., La Porta, R., López-de-Silanes, F., Shleifer, A., \& Volokh, A. (2003). Judicial reform. The World Bank Research Observer, 18(1): 61-88. doi: https://doi.org/10.1093/wbro/lkg005

Buchanan, J.M., \& Tullock, G. (1999). The calculus of consent: the logical foundation of constitutional democracy. Available from: <http://www.econlib.org/library/ Buchanan/buchCv3c3.html>. [Accessed: 21 October 2020]

Crowley, D. W. (1987). Judicial review of administrative agencies: Does the type of agency matter? The Western Political Quarterly, 40(2): 265-283. doi: https://doi.org/10.1177/106591298704000205

EBRD European Bank for Reconstruction and Development (2012). Global Practice Guide: Public Procurement, prepared by Lex Mundi. Available from: < http://www.lexmundi.com/lexmundi/Public_Procurement_Guide2.asp>. [Accessed: 23 September 2020]

EBRD European Bank for Reconstruction and Development (2013). Public Procurement Sector Assessment: Review of Laws and Practice in the SEMED region - Egypt, Jordan, Morocco, Tunisia. Available from: <http://www.marchespublics.gov.tn/ onmp/upload/documents/ebrd_report_eng.pdf>. [Accessed: 08 October 2020]

Emmert, C.F. (1992). An integrated case-related model of judicial decision making: Explaining state Supreme Court decisions in judicial review cases. The Journal of Politics, 54(2), 543-552. doi: https://doi.org/10.2307/2132038

Gillespie, J. (2007). Rethinking the role of judicial independence in socialist-transforming East Asia. The International and Comparative Law Quarterly, 56(4): 837-869. doi: https://doi.org/10.1093/iclq/lei203

Government Tenders and Procurement Law (GTPL) (2019). Government Tenders and Procurement Law, Articles 1-87. Financial Knowledge Center, Ministry of Finance. Available from: <https://www.mof.gov.sa/en/Documents/Government_Tenders_ and_Procurement_Law.pdf >. [Accessed: 15 June 2020]

Hofmann, V, Rowe, R.C., \& Turk, A. (2011). Administrative Law and Policy of the European Union. Oxford University Press, Oxford, United Kingdom.

Institute for Public-Private Partnerships (IPPP) (2003). Review and analysis of the Egyptian Tender Law and its Executive regulations. Governorate of Alexandria, Governorate of Cairo, Governorate of Qalyoubiya, Egyptian Environmental Policy Program, and the United States Agency for International Development. Available from: <https://www.scribd.com/document/216672276/Review-and-Analysis-of-theEgyptian-Tender-Law-and-Its-Executive-Regulations>. [Accessed: 12 July 2020] 
Kapiszewski, D. (2011). Tactical balancing: High court decision making on politically crucial cases. Law and Society Review, 45(2): 471-506. doi: https://doi.org/10.1111/ j.1540-5893.2011.00437.x

Kerur, S., \& Edwards, C. (2020). The New KSA Government Tenders and Procurement Law. Reed Smith driving through partnership, Dubai. Available from: $<$ https://www.reedsmith.com/en/perspectives/2020/02/the-new-ksagovernment-tenders-and-procurement-law>. [Accessed: 20 August 2020]

Lehmkuhl, D. (2008). On government, governance and judicial review: The case of European Competition Policy. Journal of Public Policy, 28(1): 139-159. doi: https://doi.org/10.1017/S0143814X08000810

Marvel, M.K., \& Marvel, H.P. (2007). Outsourcing oversight: a comparison of monitoring for in-house and contracted services. Public Administration Review, 67(3): 521-530. doi: https://doi.org/10.1111/j.1540-6210.2007.00734.x

Massengale, E.W. (1991). Fundamentals of Federal Contract Law. Praeger Publishers, Westport, United States.

Ministry of Foreign Trade (2002). Developing a Procurement Reform Program Supporting SME Development in Egypt: A Background Study. Available from: <http://www.mof.gov.eg/MOFGallerySource/English/SME/Research_studies/4.pd f>. [Accessed: 13 January 2016]

Nagle, J.F. (2000). How to review a federal contract and research federal contract law. American Bar Association, Chicago, United States.

Organization for Economic Cooperation and Development (OECD) (2016). Stocktaking Report on MENA Public Procurement System, MENA-OECD Network on Public Procurement, Paris: OECD. Available from: <https://www.oecd.org/governance/ ethics/Stocktaking_MENA_Public_Procurement_Systems.pdf>. [Accessed: 02 December 2020]

Organization for Economic Cooperation and Development (OECD) (2014). Business Climate Review of Egypt: Investment Policies and Public Private Partnerships, Paris: OECD. Available from: <http://www.oecd.org/mena/competitiveness/ BCR\%20Egypt_April29_with_cover.pdf>. [Accessed: 22 January 2021]

Posner, E. (2008). Does political bias in the judiciary matter?: Implications of judicial bias studies for legal and constitutional reform. The University of Chicago Law Review, 75(2): 853-883. doi: http://dx.doi.org/10.2139/ssrn.1082055

Salama, A.A. (1984). International contracts for investment and economic development. Cairo, Egypt.

Saleh, Y. (2020). Egypt: The new Public Contracts Law No. 182 of 2018. Lexocology, London. 
Sunkin, M. (1987). What is happening to applications for judicial review?. The Modern Law Review, 50(4): 432-467. doi: https://doi.org/10.1111/j.14682230.1987.tb01720.x

World Bank (2003), Arab Republic of Egypt Country Procurement Assessment Report, December 2003 Operational Core Services Middle East and North Africa Region. Available from: <http://siteresources.worldbank.org/INTMNAREGTOPGOVER NANCE/Resources/CPAREGYPT2003.pdf>. [Accessed: 17 October 2020]

Conflict of Interest Statement: The author(s) declares that the research was conducted in the absence of any commercial or financial relationship that could be construed as a potential conflict of interest.

Copyright: (c) HALREV. This is an open access article distributed under the terms of the Creative Commons Attribution 4.0 International License (CC-BY 4.0), which permits unrestricted use, distribution, and reproduction in any medium, provided the original author and source are credited.

Hasanuddin Law Review (Hasanuddin Law Rev. - HALREV) is an open access and peer-reviewed journal published by Faculty of Law, Hasanuddin University, Indonesia. 